\title{
Bringing Santa Rosa Island into Channel Islands National Park: the written documents 1979-1987
}

\author{
Kate Roney FaulKner* \\ Retired. Channel Islands National Park, U.S. National Park Service, 1901 Spinnaker Drive, Ventura, CA 93001
}

Aвstract.-The National Park Service (NPS) purchased Santa Rosa Island from private landowners Vail \& Vickers in 1986. Immediately following the purchase, NPS personnel stated that they and the former landowners were negotiating a 5- to 10-year phaseout of cattle ranching and hunting of introduced deer and elk. Later, NPS staff stated that the former landowners had a 25-year right to presale land uses. This unsubstantiated "right" became the justification for the NPS issuing a series of permits that continued the operations of the former landowner. Over time, questions arose regarding the environmental impacts of the cattle, deer, and elk on Santa Rosa Island's natural and archeological resources and the restricted public use of the island. Approximately 10 years after purchasing the island, the National Park Service was sued by an environmental group. Vail \& Vickers countersued. The litigation brought to light the written documents associated with the purchase of the island. The court cases were settled through a voluntary agreement which directed a rapid end to grazing of cattle and a phased reduction of deer and elk. This paper examines the written documents from 1979 to 1987, which is the period contemporaneous to the establishment of Channel Islands National Park, the sale of Santa Rosa Island, and the initiation of island management by the National Park Service. Later documents and statements will be compared to the contemporaneous documents to better understand the controversies, public perceptions, and lawsuits.

Resumen.—El Servicio de Parques Nacionales (NPS por sus siglas en inglés) compró la Isla Santa Rosa a propietarios privados, Vail \& Vickers, en 1986. Inmediatamente después de la compra, el NPS declaró que, tanto ellos como los antiguos propietarios, estaban negociando un abandono progresivo (de cinco a diez años) de la práctica de cría de ganado y de la caza de ciervos y de alces introducidos en la isla. Más tarde, el personal del Servicio de Parques Nacionales declaró que los antiguos terratenientes tenían un derecho a 25 años de uso de las tierras pre-venta. Este "derecho" sin fundamento se convirtió en la justificación para que el Servicio de Parques Nacionales emitiera una serie de permisos que continuaran con las operaciones de los antiguos propietarios. Con el tiempo surgieron preguntas acerca de los impactos ambientales del ganado, los ciervos y los alces sobre los recursos naturales y arqueológicos de la isla Santa Rosa y sobre la restricción del uso público de la isla. Aproximadamente diez años después de comprar la isla, el Servicio de Parques Nacionales fue demandado por un grupo ambientalista. Vail y Vickers contratacaron. El litigio reveló los documentos asociados a la compra de la isla. Los casos judiciales fueron resueltos mediante un acuerdo voluntario del abandono inmediato de la práctica de pastoreo de ganado y a una reducción gradual de los ciervos y los alces. Este artículo examina los documentos escritos entre 1979 y 1987; el período contemporáneo al establecimiento del Parque Nacional de las Islas del Canal (Channel Islands National Park), la venta de la Isla Santa Rosa y el inicio de la administración de la isla por parte del Servicio de Parques Nacionales. Se compararán documentos y declaraciones posteriores con documentos contemporáneos para una mayor comprensión de las controversias, percepciones públicas y demandas judiciales.

Santa Rosa Island, approximately 52,500 acres $^{1}$, is the second largest of the 5 islands within Channel Islands National Park (CINP). The island was in private ownership at the time of the establishment of CINP in 1980
(U.S. Congress 1980) and remained in private ownership until sold to the federal government in December 1986 (Warranty Deed 1986). The circumstances surrounding the acquisition and management of Santa Rosa Island by the

\footnotetext{
${ }^{1}$ Santa Rosa Island was estimated to be 52,565 acres at the time of the land appraisals prior to the 1986 sale. This paper will use "approximately 52,500 acres" for the size of the island. The current NPS estimate of the island size is 53,364 acres (R. Rudolph, personal communication, 2017).
}

*Corresponding author: kerfaulkner@gmail.com 
National Park Service (NPS) were the subject of controversy and lawsuits.

The NPS was sued in 1996, nearly 10 years after purchase of Santa Rosa Island, by the National Parks and Conservation Association (NPCA) regarding the management of the island (National Parks and Conservation Association v. Roger Kennedy et al. 1996). Shortly thereafter, Vail \& Vickers $(\mathrm{V} \& \mathrm{~V})$ filed a lawsuit with the court against the NPS (Vail, Alexander Lennox vs. Denny Galvin and Bruce Babbit 1997, Vail and Vickers 1997). The lawsuits prompted the discovery of documents from 1979 to 1987, which was the period contemporaneous to the establishment of CINP, the purchase of the island, and the initiation of management by the NPS.

\section{HisTORY}

\section{Legislation to Establish Channel Islands National Park}

(1979-1980)

Legislation to expand the existing Channel Islands National Monument was considered in the U.S. Senate and House of Representatives in 1979 and 1980. The proposed national park included the 5 northern Channel Islands (Santa Rosa, Santa Cruz, San Miguel, Anacapa, and Santa Barbara Islands) and the surrounding one nautical mile of ocean. At the time, Santa Rosa and Santa Cruz Islands were privately owned. Vail \& Vickers, the owners of Santa Rosa Island, and others initially opposed the inclusion of the island in the park (U.S. Senate 1979, Kelly 1983). Vail \& Vickers participated in congressional hearings. They both expressed concern regarding the potential of being inholders in the proposed national park and allowed an appraisal of their property by the NPS (U.S. Senate 1979).

During the congressional hearings, there was considerable discussion regarding permissible activities on privately owned land in the park and the methods and timing of acquisition by the NPS. All statements indicated that the then-current operations of the private landowners could continue under private ownership (U.S. Senate 1979). Congressman Lagomarsino stated that "acquisition of Santa Rosa Island take priority over acquisition of other privately-owned lands within the park. It is also my intention that, pending acquisition, the landowners be permitted to continue existing uses of their land" (U.S. Congressional Record - House 1980). Nonetheless, V\&V requested that Santa Rosa Island be the highest priority for acquisition by the NPS due to their fears "that the restrictions imposed by Park Service acquisition and inholding policies will not be compatible with either normal ranch building and maintenance, nor the required access for transport of personnel, supplies, and cattle" (U.S. Senate 1979).

The legislation creating CINP, which passed in March 1980 (U.S. Congress 1980), identified Santa Rosa Island as the highest priority for acquisition and indicated that if the land were to be sold to the federal government, the landowners could choose to either retain rights for up to 25 years following sale of their land to the U.S. government or negotiate a lease 2,3 (U.S. Congress 1980).

\section{Negotiations and Sale of Santa Rosa Island to the U.S. Government}

(1981-1986)

In 1983, the NPS produced a draft Land Protection Plan (NPS 1983). The draft plan did not have a clear priority to acquire Santa Rosa Island in advance of acquiring private property on Santa Cruz Island. V\&V protested and requested that "the Draft Plan should be amended to give first priority, as P.L. 96-199 requires, to acquisition of Santa Rosa Island"4 (Kelly 1983). NPS revised the final plan to move Santa Rosa Island to the highest priority for land acquisition (NPS 1984).

In 1985, NPS and V\&V had agreed on a price of $\$ 29.6$ million for the sale of the island.

\footnotetext{
2 "The owner of any private property may, on the date of its acquisition and as a condition of such acquisition, retain for himself a right of use and occupancy of all or such portion of such property as the owner may elect for a definite term of not more than twenty-five years... The owner shall elect the term to be reserved." (U.S. Congress 1980).

${ }^{3}$ The CINP legislation uses the term "lease" for a postacquisition agreement between the NPS and V\&V to allow V\&V to continue any existing uses on the portion of the island for which $V \& V$ did not retain rights to use and occupancy, and that is the term used in this paper. Other words for a lease (lease-back, leaseback, lease back, and lease back agreement) are used in cited documents. When quoted in this paper, the variant of lease is as written in the original document. Merriam-Webster (1996) defines lease as "a contract by which an owner of property conveys exclusive possession, control, use, or enjoyment of it for a specified rent and a specified term after which the property reverts to the owner; also: the act of such conveyance or the term for which it is made."
} 
This price included $V \& V$ holding a 25-year residential use and occupancy for a 7.6-acre portion of the ranch building complex (Kelly 1985b). Conclusion of the sale was pending final resolution of an ultimately unsuccessful lawsuit brought on behalf of the Chumash Native Peoples (Chunie v. Ringrose et al. 1986, Kelly 1986a). Negotiations for the cost to $\mathrm{V} \& \mathrm{~V}$ to continue ranching or hunting operations on the remainder of the island, as permitted in the CINP legislation, continued into 1986 (MacDonald 1986a, 1986b, Kelly and Sorenson 1986, White 1986).

As the end of 1986 approached, an agreement had not been reached regarding the fair market value of continued ranching and hunting on Santa Rosa Island. Acquisition of private property by the federal government must follow federal law regarding uniform standards for appraisal and acquisition of property (U.S. Congress 1970). The NPS appraised the value of various durations of land use and the retention of rights versus lease. An appraisal report transmitted by NPS to V\&V in May 1986 (MacDonald 1986a) included the cost of several options for $V \& V$ to retain rights to use and occupancy of the entire island for cattle grazing and hunting operations for periods of 5 , $10,15,20$, and 25 years. Retention of the right to continue existing operations for 25 years, the maximum duration allowed under the law establishing CINP, would have reduced the sale price of the island by $\$ 3,502,000$.

The NPS also prepared an "appraisal supplement" for $\mathrm{V} \& \mathrm{~V}$ that estimated annual fair market rental values for a potential lease agreement at $\$ 313,500$ per year for the cattle operation and $\$ 100,000$ per year for commercial hunting (MacDonald 1986b). Vail \& Vickers felt that the valuation of retained rights or lease was "far in excess of what can be supported today by a ranching operation" (Kelly and Sorenson 1986).

Vail \& Vickers pushed to conclude the land sale prior to the end of 1986 . Vail \& Vickers's legal representatives argued to NPS that "any delay in the transfer beyond the end of 1986 will cost the owners several millions of dollars as a result of the elimination of the capital gains rate by the Tax Reform Act of 1986" (Kelly and Sorenson 1986).

Sale of the island would preclude retention of any additional rights by $\mathrm{V} \& \mathrm{~V}$ beyond the 7.6-acre residential use and occupancy. The NPS questioned whether even a lease could be negotiated post sale (Ehorn 1986). The lawyers representing $\mathrm{V} \& \mathrm{~V}$ responded to NPS that "the owner has a right to a reservation, but the former owner may only request the Secretary to enter into a lease agreement" (Kelly and Sorenson 1986, emphasis in original).

The NPS agreed to move ahead with the sale with the written stipulation that the sale would not guarantee continuation of ranching or hunting operations. NPS informed $V \& V$ via letter that if they were to sell, their operations would be permitted for 3 months. Following that, the ranching operations could be terminated if lease negotiations were not successful ${ }^{5}$ (Haberlin 1986).

With this information, Vail \& Vickers sold the island to the federal government in the final days of 1986 (Warranty Deed 1986). They reserved a right to "use and occupancy" of a 7.6-acre area within the ranch complex for a period of 25 years. The remainder of the approximately 52,500-acre island was sold without any retained rights.

\section{Announcement of Purchase of Santa Rosa Island and Rental Negotiations}

(1987)

The acquisition of Santa Rosa Island was formally announced to the public approximately 1.5 months following the land sale. The NPS and Congressman Robert J. Lagomarsino, U.S. Representative from 1974 to 1992 of the congressional district including Santa Rosa Island and cosponsor of the legislation establishing CINP, issued a press release

\footnotetext{
4 "However, the owners of Santa Rosa concluded that the continuation of their ranching operations was incompatible with the stringent inholding management policies of the National Park Service. This fundamental incompatibility caused the owners and Committee staff to abandon their attempts to devise language providing for the continuation of the ranch within the park. .. Vail \& Vickers then submitted a letter to the Committee requesting that Santa Rosa Island be excluded from the park. Failing exclusion, the owners asked that 'Santa Rosa be included in the park, condemned, and the owners paid the fair market value for it at once."” (Kelly 1983).

5 "Upon conveyance of the property, your clients' continued use of the Island for livestock ranching and/or hunting will be authorized by a three month permit that will require payment of rent, which rent will be based on an approved appraisal by the National Park Service. This permit arrangement is a temporary and interim measure pending the outcome of negotiations with your clients to either authorize such uses of the Island through a lease or terminate such uses." (Haberlin 1986).
} 
regarding the purchase of Santa Rosa Island by the NPS and the on-going negotiations with $V \& V$ to maintain their operations under a "five-year lease-back arrangement" (Lagomarsino 1987a). Additionally, a public media event was held at CINP headquarters. The continuation of land uses by the former landowner was described by government officials in various terms, such as phaseout, five to ten years, five years, or several additional years. Several local media reported the story and described the 5-year or 5- to 10-year phaseout of V\&V's land uses (Catalina Islander 1987, Los Angeles Times 1987, Malibu Times 1987, Thousand Oaks News Chronicle 1987, Ventura Star Free Press 1987a, 1987b). In response to an article in a local newspaper, Bill Ehorn, CINP Superintendent from 1974 to 1989, wrote "Santa Rosa Island ... is still being used as a working cattle ranch by its recent owners, Vail \& Vickers, and they have the option of leasing back the entire island to continue their ranching operation for several additional years" (Ehorn 1987a).

As the critical 3-month period following the purchase of the island was coming to a close, elected politicians began to express concerns and question the appraisals produced by NPS real estate professionals (Lagomarsino 1987b, Wilson 1987a, 1987b, 1987c). Senator Pete Wilson wrote, "It is my understanding that the terms described in that report provide a serious disincentive to Vail \& Vickers for a five to ten year leaseback. ... The Report calls for a $\$ 313,500$ per year charge for each of the first five years up to a total of some $\$ 3$ million for up to twenty-five years. ... It appears to me to be in the interest of the government to provide the incentive for Vail \& Vickers to continue their operations for the short term, five to ten years, and to phase out their cattle operations during that tenure.... I await the requested information that will no doubt prove of great value as we consider supplemental appropriations requests in the coming months" (Wilson 1987b). In a second letter, Senator Wilson transmitted V\&V's assessment of the rental value of the island, a lesser amount than determined by NPS, as the "more accurate" evaluation and requested that the government "permit Vail and Vickers to lease back this property and phase out their traditional ranching operations over a five to ten-year period" (Wilson 1987c). Congressman Lagomarsino also wrote on behalf of $\mathrm{V} \& \mathrm{~V}$ requesting they be permitted to "continue operation of the cattle ranch on approximately 51,000 acres for a five to ten year period." Congressman Lagomarsino also rebutted the NPS appraisal of the value of the lease and requested "a more realistic and accurate evaluation” (Lagomarsino 1987b). The NPS responded to the criticisms of the appraisals detailing the "extensive analysis of comparable livestock ranching and grazing rental properties. ... The appraisal was reviewed and approved by the Chief Appraiser of the National Park Service as complying with the Uniform Appraisal Standards for Federal Land Acquisitions" (Mott 1987).

During the first year following acquisition, the controversies and discussions were largely confined to $\mathrm{V} \& \mathrm{~V}$, select NPS personnel, and politicians responsive to $\mathrm{V} \& \mathrm{~V}$ (Ehorn 1987b, 1987c, Lagomarsino 1987b, MacDonald 1987, Mott 1987, Wilson 1987a, 1987b, 1987c). National Park Service staff discussed their legal and policy responsibilities against the external pressures. Cost was the major sticking point in the negotiations for the continuation of ranching and hunting operations. Superintendent Ehorn supported decreasing the rent to be paid by V\&V to an amount "Vail \& Vickers have agreed to" and provided several justifications for the recommended reductions (Ehorn 1987c). The NPS responded to the elected officials by lowering the fair market valuation of a permit for ranching and hunting. National Park Service Director William Mott wrote, "We have, therefore, decided to refine our approach ... acceptable to the previous owners" (Mott 1987).

Nonetheless, as of the fall of 1987, more than 6 months after the 3-month period allowed for continuation of ranching and hunting on Santa Rosa Island, there was still no agreement between the NPS and V\&V. There was also no change in $V \& V$ 's operations on the now-public island.

In October 1987, an NPS ranger was quoted in a newspaper as saying: "Vail and Vickers Co. ... retains the right to ranch it [Santa Rosa Island] for up to 25 years" (Chicago Tribune 1987). Shortly afterwards, CINP Superintendent Ehorn wrote in an internal NPS memo that "an element of the sales contract noted the vendors' $[\mathrm{V} \& \mathrm{~V}]$ wish to enter into a leaseback agreement for almost the entire remainder of the island in order 
that they might continue their ranching and commercial hunting operations." Ehorn's memo also indicated the anticipated period for the private operation to be "from five to ten years" (Ehorn 1987b).

Exactly one year after the sale of Santa Rosa Island, a 5-year Special Use Permit for ranching and hunting was issued "not to exceed $\$ 80,000$ per year” (NPS 1987). The greatly reduced rent was justified by the "very restrictive" nature of the Special Use Permit (MacDonald 1987).

\section{Allegations of Violations by the NPS}

(1990s)

The 1990s was a period of conflict between the NPS and V\&V and internally within the NPS. Park biologists and others expressed concerns regarding impacts of cattle, deer, and elk on island vegetation, wildlife, soils, and water quality. They felt that CINP was not complying with federal regulations or NPS policies regarding the management of $\mathrm{V} \& \mathrm{~V}$ operations on Santa Rosa Island (Channel Islands National Park Staff 1991, Huddlestun 1992, Faulkner 1992, Vail and Vickers 1992, Setnicka 1993, Faulkner 1995). The U.S. Fish and Wildlife Service proposed listing of 10 plant species on the island under the Endangered Species Act due to impacts from soil erosion, cattle, elk, and deer (USFWS 1995). The state of California issued a Clean Up or Abatement Order against the NPS, charging violations of the Regional Water Quality Control Plan due to discharge of pollutants from the ungulates and soil erosion (California Central Coast Water Quality Control Board 1995).

National Park Service biologists and partners had collected much of the biological and physical data that supported the concerns of environmental agencies and organizations. However, many park staff, including the CINP superintendent, alluded to an oral agreement with $V \& V$ as the primary obligation for the NPS on Santa Rosa Island ${ }^{6,7}$ (Shaver 1992, Setnicka 1992, Los Angeles Times 1995). Information provided to the general public by NPS staff in leadership positions supported the contention that $V \& V$ had retained rights to utilize the entire island for grazing and hunting (Shaver 1994) and without the agreement "Vail \& Vickers company would not have sold the island." (Shaver 1995a, 1995b).

In 1996 the NPCA filed a lawsuit against the NPS alleging violations of the National Environmental Policy Act, the Endangered Species Act, the Coastal Zone Management Act, the Clean Water Act, and the NPS Organic Act (National Parks and Conservation Association v. Roger Kennedy et al. 1996). Vail \& Vickers also sued the NPS, alleging violations of the legal and oral obligations of the NPS to allow their continued ranching and hunting operations on Santa Rosa Island (Vail and Vickers 1997).

The lawsuits brought scrutiny by Department of the Interior and Department of Justice lawyers of the management decisions at CINP. The federal lawyers, in spite of contrary statements by current and former CINP superintendents, did not find evidence to support an obligation on the part of the NPS to permit $V \& V$ 's operations. $V \& V$ thus became the only party to the lawsuits arguing to the court that the CINP legislation and subsequent agreements required continued permitting of the ranching and hunting operations 8 (Ehorn 1997, Lagomarsino 1997, Vail and Vickers 1997).

Vail \& Vickers submitted declarations to the federal court (Vail, Alexander Lennox vs.

\footnotetext{
6 "However, the administrative history of the purchase of Santa Rosa Island is clear that the intent was to allow the former owners non-commercial use and occupancy of specified residential property and continued rights to conduct ranching and commercial hunting operations on the island, without unreasonable interference, by permit for 25 years from purchase, as long as these activities ae compatible with park purposes." (Shaver 1992).

7 " "There is very little evidence that the existing cattle ranch is forcing these species into oblivion, yet this order (CAO from State) has the force of law,' said Tim Setnicka, assistant superintendent of the Channel Islands National Park. ... The park service bought the land from Vail \& Vickers in 1986 for $\$ 30$ million, on the condition that the company be allowed to continue ranching for 25 more years. ... Setnicka said the park service is caught in the middle, trying to uphold its agreement with Vail \& Vickers while fending off complaints from conservation groups and environmental attorneys. ... Hopefully, he said, the plan can avoid infringing on the agreement with Vail \& Vickers.” (Los Angeles Times 1995).

8 "Furthermore, even though Vail \& Vickers knew that the special use permits were 'revocable,' that does not mean that Vail \& Vickers knew that NPS would renege on NPS's overarching promise to allow Vail \& Vickers to ranch on the Island for 25 years in compliance with CINPA [Channel Islands National Park Act]. CINPA does not allow NPS to reduce or restrict Vail \& Vickers' right to use the island for its historic ranching and hunting operations unless such operations are incompatible with the administration or with the preservation of the resources therein.' ... The dispute in this case is whether such operations were 'incompatible with ... the preservation of the resources therein.'” (Vail and Vickers 1997).
} 
Denny Galvin and Bruce Babbit 1997, Ehorn 1997, Lagomarsino 1997, Vail and Vickers 1997) supporting the claims that (a) Congress intended for $\mathrm{V} \& \mathrm{~V}$ to continue their ranching and hunting operations after sale of the island; (b) $\mathrm{V} \& \mathrm{~V}$ was forced to sell Santa Rosa Island; (c) the sale included a guarantee that $V \& V$ could continue ranching and hunting for 25 years; and (d) the NPS could only enact restrictions if the ranching/hunting was inconsistent with protection of the resources.

Both former Congressman Robert Lagomarsino and former CINP Superintendent Bill Ehorn submitted declarations in support of V\&V. Lagomarsino wrote, "It was my intent, and that of Congress that cattle ranching and elk and deer operations continue for at least twenty five years" (Lagomarsino 1997). Ehorn wrote, "William Whalen, then Director of the National Park Service, [stated] that Vail \& Vickers would be allowed to continue a viable ranching operation for a period of up to twenty-five years. ... Absent assurances that ranching operations would be permitted to continue, I believe that Santa Rosa Island would not have been included in the park" (Ehorn 1997). In addition, legislation was introduced in Congress by 2 U.S. Representatives, George Radanovich and Don Young, to pressure the NPS to permit continuation of $\mathrm{V} \& \mathrm{~V}$ 's operations and to "honor agreements reached in the acquisition of Santa Rosa Island, California, by the National Park Service" (Radanovich and Young 1997).

U.S. District Court Judge William Rea reviewed the documents submitted by all parties. He concluded that (a) the legislative history indicated that even congressional advocates for $\mathrm{V} \& \mathrm{~V}$ were not acting under the impression that the ranching and hunting operations would continue until the year 2011; (b) V\&V's entire complaint-that they were given the right to continue an economically viable ranching and hunting operation on Santa Rosa Island for 25 years-was contrary to the express language of the legislation establishing CINP, the written agreements memorializing the conveyance of Santa Rosa Island to the United States, and the permit from NPS to V\&V; (c) there was no agreement to permit $V \& V$ to continue a viable hunting and ranching operation after the sale of the island; (d) options to continue ranching and hunting operations had been available to
$\mathrm{V} \& \mathrm{~V}$, but they did not choose them; (e) $\mathrm{V} \& \mathrm{~V}$ chose to sell their property to the government without reserving any right to grazing and hunting; and (f) $V \& V$ and their supporters seem to have been under the impression that a guaranteed 25 years continuance did not exist (Rea 1997).

The preliminary ruling by Judge Rea prompted the primary parties in both lawsuits to begin negotiations towards a Settlement Agreement. The NPS, NPCA, and V\&V signed a Settlement Agreement in 1998 (U.S. District Court 1998). This agreement became the primary guiding document for permitting of ranching and hunting on Santa Rosa Island through 2011 when these uses would be ended. As a result, cattle were removed from the island in 1998. Deer and elk populations were to be managed below agreed limits and eliminated by the end of 2011 .

\section{Discussion}

The documents from 1979 to 1987 (contemporaneous to the establishment of CINP, the sale of Santa Rosa Island to the U.S. government, and initial management of the island by the NPS) provide an opportunity to evaluate the circumstances, communications, and roles of the involved parties. These documents are different from, and sometimes contradict, information available to the general public through the media or through correspondence and statements by NPS officials.

In response to management actions by NPS and the lawsuit by the NPCA, V\&V claimed (Vail and Vickers 1997, Vail 2007) that (a) Congress intended that $V \& V$ could continue ranching and hunting following sale of the island to the NPS, (b) the NPS threatened $V \& V$ with condemnation and the sale of Santa Rosa Island was against the desire of $\mathrm{V} \& \mathrm{~V}$, (c) the sale of Santa Rosa Island included a guarantee to continue ranching and hunting beyond the initial 3-month post-sale period, and (d) an unwritten agreement existed between the NPS and $V \& V$ at the time of sale to allow continued ranching and hunting.

The claims of $V \& V$ were supported in statements by U.S. Congressman Lagomarsino and former CINP Superintendent Ehorn (Ehorn 1997, 2007, Lagomarsino 2007). However, judicial review was not favorable to any of the claims (Rea 1997). Nonetheless, 
unsupported claims regarding a governmental guarantee to allow $\mathrm{V} \& \mathrm{~V}$ to continue ranching and hunting after the sale of Santa Rosa Island continued (Setnicka 2006, Dagget 2007, Vail 2007, Santa Ynez Valley Journal 2011, Daily 2012).

The contention that Congress intended that $\mathrm{V} \& \mathrm{~V}$ could continue ranching and hunting following sale of the island to the NPS or that then-director of the NPS, William Whalen, assured Congress that "Vail \& Vickers would be allowed to continue a viable ranching operation for a period of up to twenty-five years" (Ehorn 1997) is not consistent with the Congressional Record. William Whalen, NPS Director during the congressional hearings, differentiated between uses that would be permitted to continue on private land within the park and those that would be allowed if NPS were to purchase the land ${ }^{9}$ (U.S. Senate 1979) and Congressman Lagomarsino stipulated that "pending acquisition, the landowners be permitted to continue existing uses of their land" (U.S. Congressional Record - House 1980).

As described by V\&V's lawyers (Kelly and Sorenson 1986), Congress allowed V\&V to either retain rights or to sell rights to the NPS. Congress also allowed discretion by the NPS to determine what, if any, uses by a former landowner might be permitted. Additionally, the year of appraisals and substantial discussions of the fair market value and costs of rights or a lease for ranching and hunting operations supports that all parties understood that continuation of either or both uses after sale of the island would lessen the sale value of the island or require monetary compensation to the federal government (Kelly and Sorenson 1986, MacDonald 1986a, 1986b, White 1986, Wooton 1986).

The contentions that NPS threatened V\&V with condemnation and that the sale of Santa Rosa Island was against the desire of $\mathrm{V} \& \mathrm{~V}$ is not supported by written documents. The suspension of condemnation of Santa Rosa
Island was discussed in House and Senate Hearings ${ }^{10}$ (U.S. Senate 1979). Vail \& Vickers worked vigorously in the years following the establishment of CINP to ensure that the NPS purchased their land as expeditiously as possible and, following the sale, thanked those who expedited the process (Kelly 1986b). The federal government had been pushed by $V \& V$ to designate Santa Rosa Island as the highest priority for acquisition ${ }^{11}$ (U.S. Senate 1979, Kelly 1983, 1985a), to modify the draft CINP Land Protection Plan to identify Santa Rosa Island as the first priority for acquisition (Kelly 1983, 1985a, Kelly and Sorenson 1986), and to complete the sale prior to the end of 1986 in spite of not having reached an agreement of fair market rent for continuation of ranching and hunting (Kelly and Sorenson 1986).

The contention that the sale of Santa Rosa Island included a guarantee to continue ranching and hunting beyond the initial 3-month post-sale period is not evident in the written records. The purchase letter from NPS (Haberlin 1986) clearly stated that ranching and hunting were authorized for "three months." Following that period, those uses could be extended or terminated. Any continuation beyond 3 months was dependent on the outcome of ongoing negotiations to reach mutually agreeable terms, conditions, and costs.

The deed for the island is silent regarding continuation of ranching and hunting. The 25-year reservation of use and occupancy for a 7.6-acre portion of the ranch building complex stipulated that it was for noncommercial uses (Warranty Deed 1986). The letter from lawyers representing $V \& V$ to NPS prior to $V \& V$ selling the island demonstrated clearly that they understood the distinction between their "right to a reservation" (Kelly and Sorenson 1986, emphasis in original) as the landowner and the position they would hold as a former landowner who could only "request" to continue to use Santa Rosa Island (Kelly and Sorenson 1986, emphasis in original). Judge Rea (1997)

\footnotetext{
9 "Mr. Chairman, on the land that will be ours and under our control, we would have no hunting. On the privately retained property, hunting could still occur.” (U.S. Senate 1979).

10 "[A]ll of the landowners ... would be suspended from condemnation[.] ... [O]n the Vail \& Vicker's ranch there will be no condemnation.” (U.S. Senate 1979).

11 "Vail \& Vickers has not made it impossible for the National Park Service to acquire Santa Rosa. On the contrary, it has sought to encourage the land acquisition process to proceed at as rapid a pace as possible. Vail \& Vickers has repeatedly sought appropriations for land acquisition, has worked closely with officials of the National Park Service at all levels, has consistently urged a prompt appraisal of Santa Rosa Island, and has cooperated with all interested parties to carry out the statutory mandate. Vail \& Vickers presently is working to encourage Congress to appropriate the balance of the funds necessary to enable the National Park Service to acquire the entirety of Santa Rosa” (Kelly 1985a).
} 
referenced "the fact that plaintiffs have received the equivalent of more than $\$ 7$ million in exchange for not reserving the right to hunt and ranch until the year 2011."

The contention of an unwritten agreement between the NPS and V\&V at the time of sale to allow continued ranching and hunting is countered by the postacquisition requests on behalf of $\mathrm{V} \& \mathrm{~V}$ to allow a short phaseout period for $V \& V$ 's operations. Elected officials wrote several letters to the Department of the Interior and the NPS requesting that the NPS allow V\&V 5 to 10 years to phase out their operations (Lagomarsino 1987b, Wilson 1987c, Lagomarsino 1987c). Several months after the purchase of the island, Superintendent Ehorn wrote to a local newspaper that $\mathrm{V} \& \mathrm{~V}$ had the option to lease the island for several additional years (Ehorn 1987a). This short phaseout period was consistent with Ehorn's later memo to the NPS Regional Director that he anticipated a period of from 5 to 10 years for a lease with V\&V (Ehorn 1987b).

In the initial months following the purchase of Santa Rosa Island by the NPS, the public information regarding the purchase is consistent with prior written documents. All statements refer to negotiations with the former landowners and the potential for a relatively short phaseout of the ranching and hunting operations over a 5 - to 10-year period The public was told that (a) the NPS had purchased the entire island; (b) V\&V reserved 25-year rights for 7.6 acres at Bechers Bay; and (c) a 5-year or a 5- to 10-year phaseout of ranching operations was being negotiated ${ }^{12}$ (Lagomarsino 1987a, Catalina Islander 1987, Los Angeles Times 1987, Malibu Times 1987, Thousand Oaks News Chronicle 1987, Ventura Star Free Press 1987a, 1987b).

In March 1987, Superintendent Ehorn responded to a local newspaper questioning when Santa Rosa Island would be open to public use. Ehorn anticipated "several additional years" for V\&V's operations on Santa Rosa Island (Ehorn 1987a). However, Ehorn, for the first time, writes that "the option of leasing" lies with $\mathrm{V} \& \mathrm{~V}$. This is a shift from all prior statements that recognize the NPS as the entity that held all options for any uses to be leased or permitted on the island ${ }^{13}$. Ehorn's writing opened a potential misunderstanding regarding the rights held by $\mathrm{V} \& \mathrm{~V}$. As lawyers representing $\mathrm{V} \& \mathrm{~V}$ had clearly articulated several months earlier (Kelly and Sorenson 1986), "The owner has a right to a reservation, but the former owner may only request the Secretary [of the Interior] to enter into a lease agreement" [emphasis in original].

The first known reference to a right to ranch for $\mathrm{V} \& \mathrm{~V}$ appeared in late 1987 when an NPS Ranger incorrectly stated (or was incorrectly quoted) that "Vail and Vickers Co. ... retains the right to ranch it [Santa Rosa Island] for up to 25 years" (Chicago Tribune 1987). Shortly afterwards, CINP Superintendent Ehorn wrote that "an element of the sales contract noted the vendors' $[\mathrm{V} \& \mathrm{~V}]$ wish to enter into a leaseback agreement for almost the entire remainder of the island" (Ehorn 1987b). Over time, CINP management staff became much more specific in stating that $\mathrm{V} \& \mathrm{~V}$ had rights to continue operations islandwide for 25 years. C. Mack Shaver, CINP Superintendent from 1989 to 1996, responded to public inquiries that "the former owners retained ... the option to continue ranching and commercial hunting under permit for twenty five years" (Shaver 1994) and "as part of the purchase agreement, the NPS agreed to allow, through a permitting system, Vail \& Vickers to continue ranching and the hunting operation in the same manner as they had, for a period not to exceed 25 years from date of purchase" (Shaver 1995a, 1995b).

A well-known law firm represented $V \& V$ throughout the drafting of the CINP legislation and the negotiations for the sale of Santa Rosa Island. Vail \& Vickers was knowledgeable regarding the tradeoffs between the sales price of the island and the rights they could retain. The oft-repeated contention that $V \& V$ were used to doing business with a handshake or relied on oral promises 14 (Radanovich and Young 1997, Vail and Vickers 1997, Los Angeles Times 1997) is not reflected in the extensive involvement of their legal counsel throughout the 1979 to 1987 period. In particular, the 1986 letter from $V \& V$ lawyers to the NPS instructing

\footnotetext{
12 "Ehorn said by March 1 he hopes for an agreement with Russ and Al Vail, ranchers who have run cattle there for years, to maintain their operations under a five-year lease-back arrangement.” (Thousand Oaks News Chronicle 1987).

13 "At present it [Santa Rosa Island] is still being used as a working cattle ranch by its recent owners, Vail \& Vickers, and they have the option of leasing back the entire island to continue their ranching operation for several additional years" (Ehorn 1987a).
} 
the government regarding the difference between a "right" and a "request" illustrates a very clear understanding of the legalities of the land sale (Kelly and Sorenson 1986).

The characterization of the purchase of Santa Rosa Island evolved over time to become "a less-than-fee sale that provided the continued rights of Vail \& Vickers to continue their commercial operations for 25 years on a not-to-interfere basis by the National Park Service." (Frisch et al. 2014). Despite later statements to the contrary, all of the primary players were clear in their writing and speech at the time of the island purchase that there was no agreement or vision to allow 25 years of ranching. The court-approved Settlement Agreement of 1998 (U.S. District Court 1998) established a new management regime for Santa Rosa Island. Cattle were removed in 1998. The 25-year use and occupancy of V\&V ended in 2011 and all personal belongings were removed. Deer and elk populations were eliminated, the final actions agreed to in the 1998 Settlement Agreement, shortly after the end of the use and occupancy (Ventura County Star 2011a). Beginning in 2012, Santa Rosa Island was fully opened to visitor use without closures for hunting operations (Ventura County Star 2011b, The Log 2012).

\section{Conclusions}

Bringing Santa Rosa Island into Channel Islands National Park was a long, complex, and controversial undertaking. The lawsuits filed by NPCA and V\&V against the NPS in 1996 and 1997, respectively, brought forth written documents from all parties. The written documents, many of which had not been publicly available prior to the court cases, did not support the existence of an agreement or any other obligation on the part of the NPS to allow $\mathrm{V} \& \mathrm{~V}$ to continue ranching and hunting operations beyond the 3 months guaranteed in the offer to purchase the island. In fact, as pointed out by Judge Rea (1997) "plaintiffs themselves and their supporters seem to have been under the impression that a guaranteed twenty-five years continuance did not exist [following the sale of the island]."

The written documents demonstrate that information provided to the public by the NPS evolved during the year following the acquisition of Santa Rosa Island. Political pressure was placed on the NPS to reduce the appraised value of commercial operations by $\mathrm{V} \& \mathrm{~V}$ during the phaseout period. The NPS complied. It is not clear why NPS officials also initiated, and defended, a broader narrative permitting the former landowner to use public land as if it were still in private ownership.

Information available through media, presentations, or directly from NPS officials frequently contradicts the written records from 1979 to 1987. Much of the publicly available information referenced words or phrases from congressional hearings or the CINP legislation, such as compatibility of grazing, agreement, deal, rights, use and occupancy, and 25 years. However, the words were frequently used in misleading or incorrect contexts. Vail \& Vickers had a very simple story as described in the Los Angeles Times (1997): "In what Vail now refers to as a gentlemen's agreement, they consented to sell the island for nearly $\$ 30$ million, and keep ranching until 2011.” In contrast, NPS officials regularly supported the story of an agreement although "there is no piece of paper that the agreement is written on" (Los Angeles Times 1997) and characterized the sale of Santa Rosa Island to the NPS as a casual deal, "like a cattle deal"15 (Los Angeles Times 1997).

It has often been said that the NPS violated the trust between the U.S. government and V\&V (Los Angeles Times 1995, Radanovich and Young 1997, Vail and Vickers 1997, Setnicka 2006, Santa Ynez Valley Journal 2011). The written record does not support this. It does, however, provide evidence of a

14 "Because Vail \& Vickers reasonably relied on such representations and were induced under the oral agreement to sell the Island, Vail \& Vickers is entitled to recessionary relief. ... NPS engaged in a pervasive ongoing pattern of promises to Vail \& Vickers from 1979 until 1996 that Vail \& Vickers would be able to continue its historic and economically viable ranching and hunting operations on the Island until 2011... NPS's overarching promise to allow Vail \& Vickers to ranch on the Island for 25 years in compliance with CINPA [Channel Islands National Park Act]. CINPA does not allow NPS to reduce or restrict Vail \& Vickers' right to use the island for its historic ranching and hunting operations unless such operations are 'incompatible with the administration or with the preservation of the resources therein.”' (Vail and Vickers 1997).

15 "Setnicka said the Vails' mistake is that the family treated their deal with the government like a cattle deal. Their downfall is, they are used to doing business on a handshake, Setnicka said ... 'I think there is a big question of trust on the part of the federal government side.” (Los Angeles Times 1997). 
violation of trust between the NPS and the American public.

The NPCA lawsuit and a federal court judge pushed the NPS toward managing Santa Rosa Island to meet the legislated public mission of Channel Islands National Park.

\section{Literature Cited}

California Central Coast Water Quality Control BOARD. 1995. Clean Up or Abatement Order for Rangeland and Road Management Activities on Santa Rosa Island, United States Department of the Interior, National Park Service, Channel Islands National Park. 95-064. 18 August 1995.

Catalina Islander. 1987. National Park Service purchases island. 13 March 1987. Page 5. NPS, Channel Islands National Park Archives, Accession \# CHIS00531 and Catalog \# CHIS 46794.

Channel Islands National Park Staff [unknown]. 1991. Justification for closing Carrington Pasture to grazing. Notes. 2 pp. NPS, Channel Islands National Park Archives, Accession \# CHIS-00531 and Cata$\log$ \# CHIS 46794.

Chicago Tribune. 1987. Santa Rosa Island a rare California adventure. Byline: Terry Young. 25 October 1987. NPS, Channel Islands National Park Archives, Accession \# CHIS-00531 and Catalog\# CHIS 46794.

Chunie v. Ringrose Et AL. 1986. F.2d 638 (9th Circuit Court of Appeals, 1986).

Dagget, D. 2007. Leaving Santa Rosa Island. Range Magazine. Spring 2007:20-23.

DAILY, M. 2012. E-mail to Kate Faulkner transmitting a 1997 letter by Al Vail. 2 pp. NPS, Channel Islands National Park Archives, Accession \# CHIS-00531 and Catalog \# CHIS 46794.

EHorn, W.H. 1986. Memo to Regional Director re: Solicitor Opinion Regarding Santa Rosa Island Acquisition. 5 December 1986. 1 p. NPS, Channel Islands National Park Archives, Accession \# CHIS-00531 and Catalog \# CHIS 46794.

EHoRn, W.H. 1987a. Letter to Santa Barbara News-Press Editor: We hasten slowly to open Santa Rosa. 15 March 1987. NPS, Channel Islands National Park Archives, Accession \# CHIS-00531 and Catalog\# CHIS 46794.

EHORN, W.H. 1987b. Memo to regional director re: Future plans for Santa Rosa Island. 1 December 1987. NPS, Channel Islands National Park Archives, Accession \# CHIS-00531 and Catalog\# CHIS 46794.

EHorn, W.H. 1987c. Memo to regional director re: Justification for adjusting appraisal fair market rent for special use permit-Santa Rosa Island, Channel Islands National Park. 22 December 1987. 2 pp. NPS, Channel Islands National Park Archives, Accession \# CHIS-00531 and Catalog\# CHIS 46794 .

EHorn, W.H. 1997. Statement of William H. Ehorn. 23 April 1997. 2 pp. NPS, Channel Islands National Park Archives, Accession \# CHIS-00531 and Catalog\# CHIS 46794.

Ehorn, W.H. 2007. Transcript of Bill Ehorn interview. 11 November 2007. 24 pp. NPS, Channel Islands
National Park Archives, Accession \# CHIS-00531 and Catalog \# CHIS 46794

FAULKNER, K.R. 1992. Memo to NPS file. 1 p. NPS, Channel Islands National Park Archives, Accession\# CHIS-00531 and Catalog \# CHIS 46794.

FaUlKner, K.R. 1995. Chronology of events associated with Santa Rosa Island controversy. Notes. 2 pp. NPS, Channel Islands National Park Archives, Accession \# CHIS-00531 and Catalog\# CHIS 46794.

Frisch, S., K. FaulKner, and D. WaKelee. 2014. Santa Rosa Island: hunting and non-native wildlife in a National Park. Annual Meeting of the Western Political Science Association. 19 April 2014.

HaberLin, E.R. 1986. Letter to Latham and Watkins. 18 December 1986. 2 pp. NPS, Channel Islands National Park Archives, Accession \# CHIS-00531 and Catalog \# CHIS 46794

Huddlestun, J. 1992. E-mail to Kate Faulkner. NPS, Channel Islands National Park Archives, Accession \# CHIS-00531 and Catalog \# CHIS 46794.

Kelly, W.C. 1983. Letter to William H. Ehorn. 21 June 1983. 5 pp. NPS, Channel Islands National Park Archives, Accession \# CHIS-00531 and Catalog\# CHIS 46794.

KeLLY, W.C. 1985a. Letter to Mr. David A. Watts, National Park Service for Latham, Watkins \& Hills. 16 April 1985. NPS, Channel Islands National Park Archives, Accession \# CHIS-00531 and Catalog\# CHIS 46794

Kelly, W.C. 1985b. Letter to the Honorable Robert J. Lagomarsino for Latham, Watkins \& Hills. 17 December 1985. 1 p. NPS, Channel Islands National Park Archives, Accession \# CHIS-00531 and Catalog \# CHIS 46794.

KeLLY, W.C. 1986a. Letter to Ms. Lori Stillman, U.S. Congress Interior Committee Minority for Latham, Watkins \& Hills. 1 p. NPS, Channel Islands National Park Archives, Accession \# CHIS-00531 and Cata$\log$ \# CHIS 46794.

KeLLY, W.C. 1986b. Letter to Michael Wooton (Office of Sen. Pete Wilson) for Latham, Watkins \& Hills. 30 December 1986. 1 p.

Kelly, W.C., and A.M. Sorenson. 1986. Memo to E.R. Haberlin re: Leasing of Santa Rosa Island for Latham, Watkins \& Hills. 11 December 1986. 5 pp. NPS, Channel Islands National Park Archives, Accession \# CHIS-00531 and Catalog\# CHIS 46794.

Lagomarsino, R.J. 1987a. Press release: Vaqueros may keep riding herd on Santa Rosa Island when it's a park. 1 p. 10 February 1987. NPS, Channel Islands National Park Archives, Accession \# CHIS-00531 and Catalog \# CHIS 46794.

Lagomarsino, R.J. 1987b. Notes of presentation at February 10, 1987 media event announcing the acquisition of Santa Rosa Island by the NPS. Robert J. Lagomarsino Collection: Federal Collection, 1974-1992. Collection Number: 1/92. Broome Library, California State University Channel Islands.

Lagomarsino, R.J. 1987c. Letter to Donald P. Hodel, Secretary of the Interior. 1 p. 24 March 1987. NPS, Channel Islands National Park Archives, Accession \# CHIS-00531 and Catalog \# CHIS 46794.

Lagomarsino, R.J. 1997. Statement of Robert J. Lagomarsino Member of Congress, 1974-1993. 22 April 1997. 2 pp. NPS, Channel Islands National Park 
Archives, Accession \# CHIS-00531 and Catalog\# CHIS 46794.

Lagomarsino, R.J. 2007. Statement of Robert J. Lagomarsino on behalf of Vail and Vickers Company Santa Rosa Island, California. 15 May 2007. 4 pp. NPS, Channel Islands National Park Archives, Accession \# CHIS-00531 and Catalog \# CHIS 46794.

Los Angeles Times. 1987. Santa Rosa Island becomes part of Channel Islands National Park. 22 February 1987. NPS, Channel Islands National Park Archives, Accession \# CHIS-00531 and Catalog \# CHIS 46794.

Los ANgeles Times. 1995. Island cleanup plan threatens cattle. Byline: Kenneth R. Weiss. 14 October 1995. NPS, Channel Islands National Park Archives, Accession \# CHIS-00531 and Catalog \# CHIS 46794.

Los ANgeles Times. 1997. Island squeeze; ranching family feels livelihood threatened by Park Service, environmentalists. Byline: Hilary E. MacGregor. http:// articles.latimes.com/1997-05-25/local/me-62369 1_channel-islands-park.

MACDONALD, J.D. 1986a. Letter re: Fair market rental values, Tract 102 - 01 (Vail \& Vickers), Santa Rosa Island, Channel Islands National Park. 29 May 1986. 1 p. NPS, Channel Islands National Park Archives, Accession \# CHIS-00531 and Catalog\# CHIS 46794.

MacDonald, J.D. 1986b. Letter re: Appraisal Supplement, fair market rental values, Tract 102-01 (Vail \& Vickers), Santa Rosa Island, Channel Islands National Park. 24 October 1986. 3 pp. NPS, Channel Islands National Park Archives, Accession \# CHIS00531 and Catalog \# CHIS 46794.

MacDonald, J.D. 1987. Memo to Chief, Division of Land Resources re: Permit fee, grazing and hunting Special Use Permit, Tract 102-01 (Vail/Vickers), Santa Rosa Island, Channel Islands National Park. 9 September 1987. 3 pp. NPS, Channel Islands National Park Archives, Accession \# CHIS-00531 and Cata$\log$ \# CHIS 46794.

Merriam-Webster. 1996. "lease”. Merriam Webster's Dictionary of Law. Merriam-Webster, Inc., Springfield, MA. 634 pp. ISBN 0-87779-604-1.

Malibu Times. 1987. Santa Rosa Island Purchased by National Park Service. 20 February 1987. NPS, Channel Islands National Park Archives, Accession \# CHIS-00531 and Catalog\# CHIS 46794.

Mотт, W.P. 1987. Letter to Senator Pete Wilson. 24 March 1987. 2 pp. NPS, Channel Islands National Park Archives, Accession \# CHIS-00531 and Catalog\# CHIS 46794.

[NPS] National Park Service. 1983. Channel Islands National Park, California; draft land protection plan. U.S. Department of the Interior.

[NPS] National Park Service. 1984. Channel Islands National Park, California; land protection plan. U.S. Department of the Interior.

[NPS] National Park Service. 1987. Special Use Permit. 29 December 1987. NPS, Channel Islands National Park Archives, Accession \# CHIS-00531 and Cata$\log$ \# CHIS 46794

National Parks and Conservation Association v. Roger Kennedy ET AL. 1996. United States District Court for the Central District of California; Case No. 96741. NPS, Channel Islands National Park Archives,
Accession \# CHIS-00531 and Catalog\# CHIS 46794.

Radanovich, G., and D. Young. 1997. House of Representatives bill to honor agreements reached in the acquisition of Santa Rosa Island, California, by the National Park Service. HR 1696. 21 May 1997. 1 p. NPS, Channel Islands National Park Archives, Accession \# CHIS-00531 and Catalog\# CHIS 46794.

REA, W.J. 1997. Tentative Ruling Case Number CV 974098; Alexander Lennox Vail, et al. v. Denny Galvin et al. U.S. District Court Central District of California. 11 August 1997. 10 pp. NPS, Channel Islands National Park Archives, Accession \# CHIS-00531 and Catalog \# CHIS 46794.

RudolPh, R. 2017. Personal communication regarding estimated size of Santa Rosa Island by the National Park Service [unpublished]. Geographic Information Systems Specialist, Channel Islands National Park.

Santa Ynez Valley Journal. 2011. On the ranch. Byline: Nancy Crawford-Hall. 7 April 2011.

SetnicKa, T.J. 1992. Memo to CINP Superintendent, Chief Ranger, and Chief Resources Management. $1 \mathrm{p}$. 12 December 1992. NPS, Channel Islands National Park Archives, Accession \# CHIS-00531 and Cata$\log$ \# CHIS 46794.

SETnICKA, T.J. 1993. Memo to CINP Superintendent re: Environmental Assessment-Fox Monitoring. 24 June 1993. 3 pp. NPS, Channel Islands National Park Archives, Accession \# CHIS-00531 and Cata$\log$ \# CHIS 46794.

SETniCKA, T.J. 2006. Santa Rosa saga (3 parts). Opinions and Letters, Santa Barbara News-Press. 8 October, 15 October and 22 October 2006. NPS, Channel Islands National Park Archives, Accession \# CHIS00531 and Catalog \# CHIS 46794.

Shaver, C.M. 1992. Memo to NPS Regional Director. NPS, Channel Islands National Park Archives, Accession\# CHIS-00531 and Catalog\# CHIS 46794 .

Shaver, C.M. 1994. Letter to R.J. Gordon. 1 p. NPS, Channel Islands National Park Archives, Accession \# CHIS-00531 and Catalog \# CHIS 46794.

Shaver, C.M. 1995a. Letter to D. Hemple. 1 p. NPS, Channel Islands National Park Archives, Accession \# CHIS-00531 and Catalog \# CHIS 46794.

Shaver, C.M. 1995b. Letter to W.N. Johson. 1 p. NPS, Channel Islands National Park Archives, Accession \# CHIS-00531 and Catalog \# CHIS 46794.

The Log. 2012. Era ends, new one begins at Santa Rosa Island. Byline: Catherine French. 17 January 2012. http://www.thelog.com/local/as-one-era-ends-a-new -one-begins-on-santa-rosa-island/

Thousand Oaks News Chronicle. 1987. Santa Rosa Island set to open in May. Byline: The Associated Press. 12 February 1987. NPS, Channel Islands National Park Archives, Accession \# CHIS-00531 and Catalog \# CHIS 46794.

U.S. CONGREss. 1970. Uniform Relocation Assistance and Real Property Acquisition Act of 1970. P.L. 91-646 as amended. 42 U.S. Code, Chapter 61.

U.S. Congress. 1980. National Parks and Recreation Act of 1978, amendment. Public Law 96-199. 5 March 1980.

U.S. Congressional Record - House. 1980. Statement of Representative Phillip Burton. 20 February 1980.

U.S. District CourT. 1998. Settlement Agreement, Case 
No. 96-7412 and Case No. 97-4098. Central District of California.

[USFWS] U.S. Fish and Wildlife Service. 1995. Proposed Rule for 16 plant taxa from the Northern Channel Islands, California. Federal Register, Vol. 60, No. 142. Page 37993. 25 July 1995.

U.S. Senate. 1979. Hearing before the Subcommittee on Parks, Recreation and Renewable Resources. 19 July 1979. Publication No. 96-63. NPS, Channel Islands National Park Archives, Accession \# CHIS-00531 and Catalog \# CHIS 46794.

Vail, Alexander Lennox vs. Denny Galvin and Bruce Baввітт. 1997. United States District Court for the Central District of California; Case No. 97-4098. NPS, Channel Islands National Park Archives, Accession \# CHIS-00531 and Catalog \# CHIS 46794.

VAIL AND ViCKERS. 1992. Letter to Mack Shaver, Superintendent Channel Islands National Park re: Environmental Assessment and Range Management Plan for Santa Rosa Island. 4 pp. NPS, Channel Islands National Park Archives, Accession \# CHIS-00531 and Catalog \# CHIS 46794.

VAIL AND Vickers. 1997. Vail \& Vickers' Reply to Oppositions to Motion for Preliminary Injunction. United States District Court Central District of California; Consolidated Case No. 96-7412. 28 July 1997.

VAIL, T.B. 2007. Statement of Timothy B. Vail, D.V.M on behalf of Vail \& Vickers Company Santa Rosa Island, California. 15 May 2007. 12 pp. NPS, Channel Islands National Park Archives, Accession \# CHIS00531 and Catalog \# CHIS 46794.

Ventura County Star. 2011a. Byline: Zeke Barlow. End of an era on Santa Rosa Island. 12 November 2011. NPS, Channel Islands National Park Archives, Accession \# CHIS-00531 and Catalog\# CHIS 46794.

Ventura County Star. 2011b. Byline: Zeke Barlow. Santa Rosa Island completely open to public. 31 December 2011. NPS, Channel Islands National Park Archives, Accession \# CHIS-00531 and Catalog\# CHIS 46794.
Ventura Star Free Press. 1987a. S. Rosa Island to become part of C.I. Park. 7 February 1987. NPS, Channel Islands National Park Archives, Accession \# CHIS-00531 and Catalog \# CHIS 46794.

Ventura Star Free Press. 1987b. Beautiful Santa Rosa joins park system. Byline: Dave Stone. 10 February 1987. Page A-10. NPS, Channel Islands National Park Archives, Accession \# CHIS-00531 and Cata$\log$ \# CHIS 46794.

WarRanty DEed. 1986. Santa Barbara County. 1986087578. NPS, Channel Islands National Park Archives, Accession \# CHIS-00531 and Catalog\# CHIS 46794.

White, W.M. 1986. National Park Service Appraisal Review. 6 pp. NPS, Channel Islands National Park Archives, Accession \# CHIS-00531 and Catalog \# CHIS 46794.

Wilson, P. 1987a. Letter to William Penn Mott, Director National Park Service. 27 January 1987. 1 p. NPS, Channel Islands National Park Archives, Accession \# CHIS-00531 and Catalog \# CHIS 46794.

WiLSON, P. 1987b. Letter to Donald P. Hodel, Secretary of the Interior. 28 January 1987. 2 pp. NPS, Channel Islands National Park Archives, Accession \# CHIS00531 and Catalog \# CHIS 46794.

Wilson, P. 1987c. Letter to Donald Paul Hodel, Secretary of the Interior. 20 March 1987. 1 p. NPS, Channel Islands National Park Archives, Accession \# CHIS00531 and Catalog \# CHIS 46794.

Wooton, M. 1986. Memo to Congressman Lagomarsino. 14 January 1986. 1 p. Robert J. Lagomarsino Collection: Federal Collection, 1974-1992. Collection Number: 1/92. Broome Library, California State University Channel Islands.

Received 1 March 2017

Revised 14 August 2017

Accepted 23 August 2017

Published online 21 November 2017 